\title{
Effect of General Allocation Fund (DAU) and Capital Expenditure on Economic Growth in West Sulawesi Province Period 2015 - 2018
}

\author{
Awal Nopriyanto Bahasoan ${ }^{1}$, Aswar Rahmat ${ }^{1}$, Andini Nurhajra ${ }^{2}$ \\ \{awalnopriyanto@unsulbar.ac.id ${ }^{1}$,aswarrahmat30@gmail.com ${ }^{1}$, sultanandini@gmail.com $^{2}$ \} \\ Universitas Sulawesi Barat, Jalan Prof. Dr. Baharuddin Lopa, S.H, Majene, Indonesia ${ }^{1}$ \\ Sekolah Tinggi Ilmu Ekonomi Panca Bhakti Palu, 1.Dr. Soeharso No. 36 A, Palu, Indonesia ${ }^{2}$
}

\begin{abstract}
This research aims to find out the purpose of study is to find out the relationship and influence of general allocation fund (DAU) and capital expenditure to the economic growth of West Sulawesi Province in the period 2015-2018. The analysis used in this study is a regression data panel. The best model that will be used to analyze the influence of capital expenditure and general allocation funds on economic growth in West Sulawesi Province during the period 2015-2018 is the fixed effect model. The results of this study conclude that capital expenditure and general allocation funds in West Sulawesi Province have a positive and significant effect on economic growth. The relationship between the general allocation fund of West Sulawesi province and economic growth, namely in terms of demand. The relationship between capital expenditure and economic growth in West Sulawesi province lies in the allocation of capital expenditures.
\end{abstract}

Keywords: Capital expenditure, Economic growth, General allocation fund.

\section{Introduction}

Law No. 22/1999 on Local Government which was later revised by Law No. 32 of 2004, in which the district was given broad authority to take care of its own households with as little central government interference as possible. Regional autonomy is a process that requires a paradigmatic transformation in the maintenance of local government. Judging from the economic aspects, the main change lies from the responsive that the sources of economic resources available in the area should be managed independently and responsibly, and the results are more focused on improving welfare and services to local communities.

Attention to regional economic growth is increasing in the era of regional autonomy, this is quite logical because in the era of autonomy each region is racing to increase its regional economic growth to increase the prosperity of its people. Economic growth factors in each region need to be known in detail as well as their properties and need to know how much influence of each of these factors in determining economic growth so that it can be used as an input for local governments in formulating the wisdom and planning of regional development [1].

Economic growth is one of the benchmarks for development success in the region. There are various indicators to measure the success of economic development in a region including 
economic growth, changes in economic structure, per capita income level (PDRB), and so on. Economic growth is a contribution to the growth of various sectors of the economy that indirectly describes the rate of economic change that occurs. For this indicator area, it is important to know the success of the development that has been achieved and useful to determine the direction of development in the future.

Development financing carried out in the region through capital expenditures and central balancing funds such as the general allocation fund (DAU) is expected to increase economic activity which will ultimately impact economic growth. According to Saragih (2004), DAU Policy is an instrument of fiscal balancing of the region. Because not all regions have the same structure and fiscal capabilities (horizontal fiscal imbalance). DAU as part of the policy of fiscal transfer from central to regional serves as a factor of fiscal equalization between regions as well as reducing the physical or financial capability gap between regions.

The general allocation fund policy (DAU) is a regional fiscal balancing instrument, as not all regions have the same structure and fiscal capability (horizontal fiscal imbalance). DAU as part of the policy of fiscal transfer from central to regional (intergovernmental transfer) serves as a factor in fiscal equalization between regions as well as reducing the physical or financial capability gap between regions. For areas with relatively few natural resources (SDA), DAU is an important source of income to support daily government operations as well as a source of development. The goal in addition to supporting the source of regional acceptance is also as equalization of the financial capabilities of the local government [2].

The general allocation fund (DAU) is a Block grant granted to all districts and cities to fill the gap between capacity and fiscal needs, and distributed with a formula based on certain principles generally indicating that poor and underdeveloped areas should receive more than rich areas. In other words, the important objective of the general allocation fund (DAU) is in terms of equalization of the ability to provide public services between local governments in Indonesia [3].

Capital expenditure is a local government expenditure whose benefits exceed one fiscal year and will increase the assets or wealth of the region and will increase regular spending such as maintenance costs in the general administration spending group [4]. Based on the Minister of State Regulation No. 37 /2014 Article 53 paragraph (1): capital expenditure as referred to in article 50 letter $\mathrm{c}$ is used for expenditures made to add/procure or build tangible fixed assets that have a benefit value of more than 12 (twelve) months for use in government activities, such as in the form of land, equipment and machinery, buildings and dams, roads, irrigation and networks, and other permanent assets.

Various studies have been conducted to understand the impact of financing done by the region on economic growth, including Widianto, Sedyautami, and Nurmansayah in 2016 in Tegal City. The results of their research show that public allocation funds negatively affect economic growth and special allocation funds affect economic growth, capital expenditure negatively affects economic growth. The negative correlation caused by tegal city local government allocating capital expenditure and general allocation funds is not based on regional needs in the end can not affect regional economic growth.

Research by Nopiani et al. (2016) in Buleleng Regency on "the influence of local native income, capital expenditures and general allocation funds on economic growth in Buleleng regency. The results of his research (1) the local native income, general allocation fund, and capital expenditure positively affect economic growth, (2) the region's original income positively affects economic growth, (3) the general allocation fund has a positive effect on economic growth, (4) capital expenditures have a positive effect on economic growth, (5) 
local native income has a positive effect on capital expenditures, and (6) general allocation funds have a positive effect on capital expenditures.

West Sulawesi is one of the new Provinces in Indonesia. Formed on October 5, 2004, West Sulawesi Province was officially formed based on Law No. 26 of 2004. In the publication Bank Indonesia explained that the Economy of West Sulawesi in 2019 is expected to grow better than in 2018. Economic growth in 2019 is expected to grow in the range of $6.9 \%-7.3 \%$ (YoY). Infrastructure development remains a mainstay to sustain the economy.

Based on the results of economic publications, the government's role in West Sulawesi Province in improving infrastructure is still very much expected to support the economy in 2019, so that dau allocation and capital expenditure need to be increased and the allocation must be appropriate for the economic outlook to be targeted. From the short results of the background explanation above, researchers are interested in researching the Influence of the General Allocation Fund (DAU) and Capital Expenditure on Economic Growth in West Sulawesi Province period 2015 - 2018.

\section{Method}

This study took the research object in 6 (six) Districts in West Sulawesi Province consisting of;(1) Majene Regency;(2) Polewali Mandar Regency;(3) Mamasa Regency;(4) Mamuju Regency; (5) Central Mamuju Regency; (6) North Mamuju Regency, with a dive research time of 3 (three) years from $2015-2016$.

The dependent variables in this study were economic growth and independent variables were general allocation funds (DAU) and capital expenditures. The data used came from the Central Bureau of Statistics of West Sulawesi Province for the period 2015-2018. The analysis used in this study was a regression of panel data. The model combines cross-sectoral observation and time-leading data so that the number of observations increases the degree of freedom and reduces the colinearity between the descriptor variables and will then improve the efficiency of econometric estimates. Verbeek (2000) suggests that the advantage of regression by using data panels compared to time or cross-sectoral data is the ability of data panel regression to identify regression parameters definitively without the need for assumptions of restrictions or constraints (see Insukindro \& Aliman, 2001). The function variable model is used to declare the relationship between independent variables and dependent variables. Here's the description of the formulation model.

\section{Economic Growth $i t=($ Capital Expenditures it DAUit $)$}

As well as the econometric model of being,

$$
Y i t=\beta 0+\log \beta 1 X 1 \text { it }+\log \beta 1 X 1 \text { it }+\varepsilon i t
$$

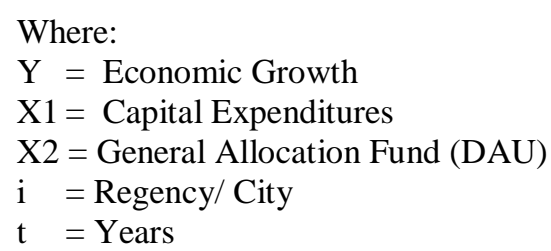


$\varepsilon=$ error value

In the discussion of the technique estimation model regression data panel, three techniques can be used namely the common effect model, fixed-effect model, and random effect model. The question that arises is which technique should be selected for the data regression panel. The common effect model is simpler compared to the other two models. Only by combining time-series and cross-section data. The data obtained are combined regardless of the difference between time and individual, so the common effect method can be used to estimate the data model of the panel.

The fixed-effect model technique is the technique of estimating panel data by using dummy variables to capture the difference in an interception. The meaning of this fixed effect is based on the difference of intersep between individual units but the intermittent intermittent intermittent (time-invariant). After regressing the two models i.e. models assuming that slope and interception are the same and models assuming that slope is the same but different intercepts, the question that arises is which model is better? Does the addition of dummy variables cause the residual sum of squares to decrease or not? The decision on whether we should add dummy variables to know that intercompany differ between companies with fixed effect methods can be tested with statistical $F$ tests.

The inclusion of dummy variables in fixed-effect models aims to represent our ignorance of the actual model. However, it also carries the consequence of a reduced degree of freedom which ultimately reduces the efficiency of parameters. This problem can be addressed by using error terms in the random effect method [8].

To determine the data panel regression model, a test of which model selection is best to use. The selection of the model was conducted using the Chow Test, Hausman Test, and Lagrange Multiplier (LM) test, in which the three tests chose which was best among common effect models, fixed effect models, or random effect models to use (Borenstein et al., 2009).

The chow test is a two-regression difference test as well as a statistical F test. Chow test is used to find out if the data panel regression technique with the fixed effect is better than the data panel regression model without dummy variables by looking at the Residual Sum of Square (RSS). The F test statistics are as follows:

$$
F=\frac{(R R S S-U R S S) /(N-I)}{U R S S /(N T-N-K)}
$$

If the F statistics > F table then the fixed effect model is better than the common effect model, thus vice versa [10].

The Hausman test is a test formally developed by Hausman. Hausman has developed a statistical test to choose whether to use a fixed-effect or random-effect model. Hausman's test is based on the idea that LSDV in fixed effect and GLS methods are efficient whereas OLS methods are inefficient, on the other hand, the OLS method is efficient and GLS is inefficient. Therefore, the null hypothesis test is that the results of the estimation of the two are not different so that the Hausman test can be done based on the difference in the estimation. Hausman's test statistics follow the distribution of Chi-Square statistics with a degree of freedom as much ask where $\mathrm{k}$ is the number of independent variables. If Hausman's statistical value is greater than its critical value then the right model is the fixed effect model whereas vice versa [11]. 
The Lagrange multiplier (LM test) test to see if the random effect model is better than the common effect method used the Lagrange multiplier (LM) test. This random effect significance test was developed by Breusch-Pagan. The Breusch-Pagan method for testing the significance of random effect models is based on the residual value of the common effect method. The LM statistical value is calculated based on the following formulas:

$$
L M=\frac{n T}{2(T-1)}\left[\frac{\sum_{i=1}^{n} e_{i t}}{\sum_{i=1}^{n} \sum_{t=1}^{n} e_{i t}^{2}}\right]^{2}
$$

This LM test is based on the distribution of chi-square with a degree of freedom amounting to the inclusion of dummy variables in the fixed effect model aimed at representing our ignorance of the actual model. However, it also carries the consequence of a reduced degree of freedom which ultimately reduces the efficiency of parameters. This problem can be addressed by using error terms in the random effect method [8].

This LM test is based on the distribution of chi-square with a degree of freedom amounting to the inclusion of dummy variables in the fixed effect model aimed at representing our ignorance of the actual model. However, it also carries the consequence of a reduced degree of freedom which ultimately reduces the efficiency of parameters. This problem can be addressed by using error terms in the random effect method [8].

\section{Results}

\subsection{Common effect approach}

The common effect model is the simplest approach of the panel data model because it only combines time series and cross-section data. In this model, it is not considered the dimensions of time or individual, so it is assumed that the behavior of the data used is considered the same in various periods. By simply combining the data without looking at the differences between time and individual, the common effect approach can be used to estimate the panel's data model. The estimated results with the common effect approach can be seen in Table 1: 
Table 1. Common Effect Model Estimation Results. Dependent Variable: Y?. Method: Pooled Least Squares. Date: 08/23/20 Time: 15:22. Sample: 2015 2018. Included observations: 4. Crosssections included: 6. Total pool (balanced) observations: 24 .

\begin{tabular}{lrlrr}
\multicolumn{1}{c}{ Variable } & Coefficient & Std. Error & \multicolumn{1}{c}{ t-Statistic } & \multicolumn{1}{c}{ Prob. } \\
\multicolumn{1}{c}{ C } & -5.590413 & 2.894016 & -1.931714 & 0.0755 \\
\multicolumn{1}{c}{ X1? } & 0.233081 & 0.084499 & 2.758389 & 0.0163 \\
X2? & 0.051485 & 0.057801 & 0.890721 & 0.3893 \\
R-squared & 0.375913 & Mean dependent var & 1.895204 \\
Adjusted R-squared & 0.279900 & S.D. dependent var & 0.098527 \\
S.E. of regression & 0.083609 & Akaike info criterion & -1.957976 \\
Sum squared resid & 0.090876 & Schwarz criterion & -1.813115 \\
Log-likelihood & 18.66381 & Hannan-Quinncriteria. & -1.950558 \\
F-statistic & 3.915215 & Durbin-Watson stat & 0.870008 \\
Prob(F-statistic) & 0.046676 & &
\end{tabular}

From the calculation using the common effect approach in table 1, it appears that capital expenditure (X1) had a positive and significant effect $(\alpha>0.05)$ on economic growth in West Sulawesi province during 2015-2018. The determination coefficient indicated by R-square of 0.37 indicates that the variation of independent variables in the model can explain the variation in the economic growth of $37 \%$, the remaining $63 \%$ is explained by other variables outside the model.

\subsection{Fixed effect approach}

In fixed-effect models, the regression intercept differs between individuals, which means each individual has different characteristics. Fixed effects are commonly used when there is a correlation between individual intercepts and independent variables. The thing to note when using fixed-effect models is that fixed-effect models cannot be used to determine the impact of variables that time-invariant, and can cause a degree of freedom problems. The estimated results with a fixed effect approach can be seen in Table 2:

Table 2. Fixed Effect Model Estimation Results. Dependent Variable: Y?. Method: Pooled Least Squares. Date: 08/23/20 Time: 16:00. Sample: 2015 2018. Included observations: 4. Crosssections included: 6. Total pool (balanced) observations: 24 .

\begin{tabular}{crrrr} 
Variable & Coefficient & Std. Error & t-Statistic & \multicolumn{1}{c}{ Prob. } \\
C & -6.422824 & 3.329517 & -1.929056 & 0.0826 \\
X1? & 0.182817 & 0.096651 & 1.891516 & 0.0878 \\
X2? & 0.131208 & 0.060477 & 2.169559 & 0.0552 \\
Fixed Effects (Cross) & & & \\
_MAJENE--C & -0.038595 & & \\
_POLMAN--C & -0.013416 & & \\
_MAMASA--C & -0.057895 & & \\
_MAMUJU--C & 0.109906 & & \\
_MAMUJUTENGAH--C & -0.018739 & & \\
_MAMUJUUTARA--C & -0.116990 & & \\
& Effects Specification & & \\
Cross-section fixed (dummy variables) & &
\end{tabular}




$\begin{array}{lrlr}\text { R-squared } & 0.722267 & \text { Mean dependent var } & 1.895204 \\ \text { Adjusted R-squared } & 0.583400 & \text { S.D. dependent var } & 0.098527 \\ \text { S.E. of regression } & 0.063594 & \text { Akaike info criterion } & -2.392605 \\ \text { Sum squared resid } & 0.040442 & \text { Schwarz criterion } & -2.102884 \\ \text { Log-likelihood } & 25.14084 & \text { Hannan-Quinn criteria. } & -2.377769 \\ \text { F-statistic } & 5.201158 & \text { Durbin-Watson stat } & 2.366418 \\ \text { Prob(F-statistic) } & 0.013073 & & \\ \text { Source: Processed data with Eviews } 11 & & \end{array}$

From the calculation using the fixed effect approach in table 2, it appears that capital expenditure (X1) had a positive and significant effect $(\alpha<0.1)$ on economic growth in West Sulawesi province during 2015-2018. The general allocation fund (X2) had a positive and significant effect $(\alpha<0.1)$ on economic growth in West Sulawesi Province during 2015-2018. The determination coefficient indicated by R-square of 0.72 indicates that the variation of independent variables in the model can explain the variation in the economic growth of $72 \%$, the remaining $28 \%$ is explained by other variables outside the model.

\subsection{Random effect approach}

The random effect model is a panel data model in which it involves the correlation between error terms due to changing times and due to different observations that can be overcome by the Error-Components model approach. The random effect model also assumes that individual intercepts are random from a larger population with constant mean value, and it is assumed that individual component errors are not correlated with each other and there is no autocorrelation either due to time-series data or because of cross-section data. The estimated results with the random effect approach can be seen in Table 3:

Table 3. Random Effect Model Estimation Results. Dependent Variable: Y?. Method: Pooled EGLS (Cross-section random effects). Date: 08/23/20 Time: 16:02. Sample: 2015 2018. Included observations: 4. Cross-sections included: 6. Total pool (balanced) observations: 24. Swamy and Arora estimator of component variances.

$\begin{array}{ccrrr}\text { Variable } & \text { Coefficient } & \text { Std. Error } & \text { t-Statistic } & \text { Prob. } \\ \text { C } & -6.238868 & 3.050596 & -2.045131 & 0.0616 \\ \text { X1? } & 0.195026 & 0.088671 & 2.199433 & 0.0465 \\ \text { X2? } & 0.112521 & 0.056769 & 1.982080 & 0.0690 \\ \text { Random Effects (Cross) } & & & \\ \text { _MAJENE--C } & -0.029225 & & & \\ \text { _POLMAN--C } & -0.007247 & & \\ \text { _MAMASA--C } & -0.050250 & & \\ \text { _MAMUJU--C } & 0.086722 & & \\ \text { _MAMUJUTENGAH--C } & -0.019274 & & \\ \text { _MAMUJUUTARA--C } & -0.044513 & & \\ & \text { Effects Specification } & & \\ & & & & \\ & & & & \\ \text { Cross-section random } & & & & \\ \text { Idiosyncratic random } & \text { Weighted Statistics } & & \\ \end{array}$




$\begin{array}{llll}\text { R-squared } & 0.367613 & \text { Mean dependent var } & 0.729222 \\ \text { Adjusted R-squared } & 0.270323 & \text { S.D. dependent var } & 0.072559 \\ \text { S.E. of regression } & 0.061981 & \text { Sum squared resid } & 0.049941 \\ \text { F-statistic } & 3.778524 & \text { Durbin-Watson stat } & 1.792218 \\ \text { Prob(F-statistic) } & 0.050861 & & \\ & \text { Unweighted Statistics } & 1.895204 \\ \text { R-squared } & 0.303889 & \text { Mean dependent var } & 0.883010 \\ \text { Sum squared resid } & 0.101363 & \text { Durbin-Watson stat } & \end{array}$

Source: Processed data with Eviews 11

From the calculation using the common effect approach in table 3, it appears that capital expenditure (X1) had a positive and significant effect $(\alpha<0.05)$ on economic growth in West Sulawesi province during 2015-2018. The general allocation fund (X2) had a positive and significant effect $(\alpha<0.1)$ on economic growth in West Sulawesi Province during 2015-2018. The determination coefficient indicated by R-square of 0.36 indicates that the variation of independent variables in the model can explain the variation in the economic growth of $36 \%$, the remaining $64 \%$ is explained by other variables outside the model.

\subsection{Determination of the best model}

\subsubsection{Test Chow}

Used to determine the best model between the common effect model and the fixedeffect model. If Chi-Square $>0.05$ then H0 is accepted, it means that the common effect model is better than the fixed effect model. If Chi-Square $<0.05$ then $\mathrm{H} 0$ is rejected, it means that the fixed effect model is better than the common effect model. Calculation results using the chow test can be seen in Table 4 below.

Table 4. Test Chow. Redundant Fixed Effects Tests. Pool: POOL01. Test cross-section fixed effects.

$\begin{array}{lrrc}\text { Effects Test } & \text { Statistic } & \text { d.f. } & \text { Prob. } \\ \text { Cross-section F } & 4.156915 & (3.10) & 0.0374 \\ \text { Cross-section Chi-square } & 12.954067 & 3 & 0.0047\end{array}$

Source: Processed data with Eviews 11

Chow test results showed that Chi-Square $<0.05$ then $\mathrm{H} 0$ was rejected, meaning that the fixed effect model was better than the common effect model.

\subsubsection{Hausman Test}

It is a test done to determine the best model between the fixed effect model and random effect model. If Chi-Square $>0.05$ then $\mathrm{H} 0$ is accepted, it means that the random effect model is better than the fixed effect model. If Chi-Square $<0.05$ then $\mathrm{H} 0$ is rejected, it means that the fixed effect model is better than the random effect model.

Table 5. Hausman Test. Correlated Random Effects - Hausman Test. Pool: POOL01. Test cross-section random effects. 
Test Summary

Cross-section random

Source: Processed data with Eviews 11 $\begin{array}{rrc}\text { Chi-Sq. Statistic } & \text { Chi-Sq. d.f. } & \text { Prob. } \\ 1.348834 & 2 & 0.0095\end{array}$

(1)

Hausman test results showed that Chi-Square $<0.05$ then $\mathrm{H} 0$ was rejected, meaning that the fixed effect model was better than the random effect model.

\subsection{Best fixed effect model}

After conducting the chow test and Hausman test to determine the best model to be used to analyze the influence of capital expenditure and general allocation funds on economic growth in West Sulawesi Province during the period 2015-2018, then the fixed effect model was selected as the best model as can be seen in Fig 1.

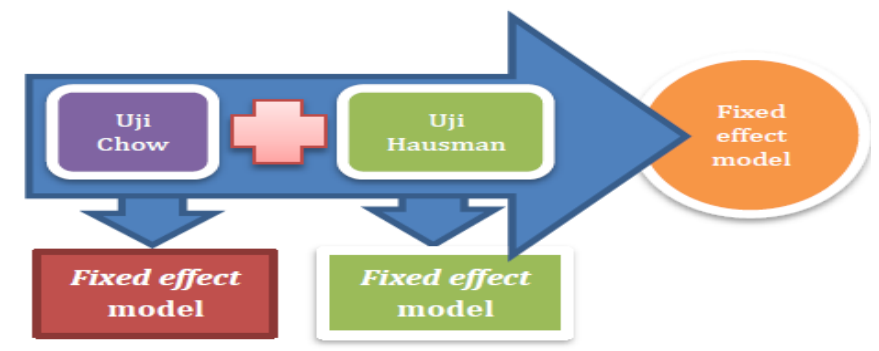

Fig. 1. The fixed effect model

Using a fixed-effect model obtained a regression coefficient value for each variable in the study with the following equations:

$$
Y=-6,42+0,18 X 1+0,13 X 2+\varepsilon
$$

\section{Discussion}

\subsection{General allocation fund and economic growth}

In-Law no. 33 of 2004 it is explained that the General Allocation Fund is a fund sourced from the State Budget allocated to equalize financial capabilities between regions to implement decentralization and regional autonomy. According to Kuncoro (2004), the General Allocation Fund is a block grant granted to all districts and cities to fill the gap between capacity and fiscal needs and distributed with a formula based on certain principles that generally indicate that poor and underdeveloped areas should receive more than rich areas.

The General Allocation Fund has a function as a fiscal equalization factor. Factors that affect the least amount of general allocation funds for each region are fiscal gap and fiscal capacity. The principle of allocation of The General Allocation Fund is for areas with great fiscal potential but whose needs are small will obtain a relatively small General Allocation Fund. Conversely, if the potential of a small area while the needs are large, then the area will 
receive a relatively large allocation of General Allocation Funds. The General Allocation Fund formula uses a fiscal gap approach, i.e. the difference between fiscal needs is reduced by the fiscal capacity of the region and the basic allocation in the form of the number of salaries of local civil servants. Based on the data in table 1, the district that received the most DAU in West Sulawesi Province during the period 2015-2018 is Polewali Mandar Regency. Mamuju Regency as the capital of West Sulawesi Province received the lowest DAU during the period 2015-2018.

Table 6. General Allocation Fund West Sulawesi Province, 2015-2018.

\begin{tabular}{|c|c|c|c|c|c|}
\hline \multirow{2}{*}{ District } & \multicolumn{4}{|c|}{ Years } & \multirow{2}{*}{ Average DAU } \\
\hline & 2015 & 2016 & 2017 & 2018 & \\
\hline Majene & 504.387 .592 .000 & 518.260 .000 .000 & 509.399 .905 .000 & 512.162 .492 .000 & 511.052 .497 .250 \\
\hline Polman & 639.371 .455 .000 & 725.382 .000 .000 & 712.638 .905 .000 & 713.339 .396 .000 & 697.682 .939 .000 \\
\hline Mamasa & 468.897 .770 .000 & 521.661 .000 .000 & 514.116 .588 .000 & 515.625 .843 .000 & 505.075 .300 .250 \\
\hline Mamuju & 563.982 .678 .000 & 626.856 .000 .000 & 189.883 .000 .000 & 219.255 .558 .042 & 399.994 .309 .011 \\
\hline MamujuUtara & 407.795 .549 .000 & 485.815 .000 .000 & 481.777 .564 .000 & 483.136 .786 .000 & 464.631 .224 .750 \\
\hline MamujuTengah & 320.285 .095 .000 & 346.913 .000 .000 & 344.886 .043 .000 & 347.815 .396 .000 & 339.974 .883 .500 \\
\hline
\end{tabular}

DAU relationship of West Sulawesi Province with economic growth, namely in terms of demand. The amount of DAU funds is largely allocated to civil servant salaries so that it greatly affects consumption through a demand-side mechanism that causes a multiplier effect, which will ultimately affect overall economic activity. Economic growth can be seen from the total national income which can also be seen from the total aggregate demand. While the element of aggregate demand is a combination of the four real sectors namely consumption, investment, government spending as well as the export and import sectors, where the total supply of goods in the economy will always be offset by the overall demand for goods and this condition causes there will be no shortage of demand.

The results of this test are relevant to the Keynes theory where economic growth is the growth of the aggregate demand component when compared to aggregate demand changes that will affect economic growth. So is the level of consumption as one component of aggregate demand. The increase in public consumption will have a positive impact on economic growth.

\subsection{Capital expenditure and economic growth}

Regulation of the Minister of Home Affairs No. 13 of 2006 explains that Capital Expenditure is part of a regional spending group that has a sense of expenditures made in the framework of purchasing/procuring or building tangible fixed assets that have a benefit value of more than twelve months to be used in government activities, such as in the form of land, machinery equipment, buildings and buildings, roads, irrigation and networks, and other fixed assets. Capital Expenditure is allocated in the hope that there is a multiplier effect (long-term effect) both macro and micro for the Indonesian economy, especially for the region. Fixed assets held as a result of Capital Expenditure are a key prerequisite in providing public services by local governments. The local government funds in the form of Capital Expenditure in the budget to increase the fixed assets owned by the region. In general, every year there is the procurement of fixed assets by local governments following a budget and public service priorities that have a long-term financial impact. Capital Expenditure is a form of regional 
financial management activities that must be managed in an orderly manner, adhere to the laws and regulations, effective, efficient, economically transparent, and responsible by taking into account the principles of fairness, compliance, and providing benefits to the community.

Based on the data obtained in table 2, North Mamuju Regency is the district in West Sulawesi Province which is the highest capital expenditure compared to other districts during the period 2015-2018. This is because North Mamuju Regency has the potential to develop the area through the plantation sector, especially palm oil, so the local government is focused on improving infrastructure through capital expenditures to support the plantation sector in the district. Majene Regency has the lowest capital expenditure value among other districts in West Sulawesi Province during the period 2015-2018.

Table 7. Capital Expenditure Growth. West Sulawesi Province, 2015-2018.

\begin{tabular}{|c|c|c|c|c|c|}
\hline \multirow{2}{*}{ District } & \multicolumn{4}{|c|}{ Years } & \multirow{2}{*}{$\begin{array}{c}\text { Average Capital } \\
\text { Expenditure }\end{array}$} \\
\hline & 2015 & 2016 & 2017 & 2018 & \\
\hline Majene & 167.696 .761 .495 & 149.384 .000 .000 & 198.434.513.429 & 160.009 .100 .975 & 168.881.093.975 \\
\hline Polman & 216.543 .680 .363 & 309.352 .000 .000 & 271.631 .463 .605 & 238.450 .051 .394 & 258.994.298.841 \\
\hline Mamasa & 298.161 .169 .227 & 326.662 .000 .000 & 235.961 .453 .240 & 186.660 .034 .003 & 261.861 .164 .118 \\
\hline Mamuju & 184.324 .866 .386 & 297.012 .000 .000 & 297.012 .000 .000 & 272.490 .620 .637 & 262.709 .871 .756 \\
\hline MamujuUtara & 276.626 .389 .532 & 341.533 .000 .000 & 342.525 .654 .602 & 279.466 .711 .293 & 310.037 .938 .857 \\
\hline MamujuTengah & 218.444 .607 .029 & 308.410 .000 .000 & 199.937.395.232 & 207.103 .951 .436 & 233.473 .988 .424 \\
\hline
\end{tabular}

Source: http://www.djpk.kemenkeu.go.id (processed)

The relationship between capital expenditure and economic growth in West Sulawesi province lies in the allocation of capital expenditures to improve the quality of infrastructure. The study of development economic theory explains that to create and increase economic activities, adequate infrastructure is needed. Infrastructure is also all the main support ingestion of a regional development process. With the increasing need for infrastructure development to support economic growth has led the Indonesian government to provide a better framework for attracting investment and private participation at a measuring scale in infrastructure projects. Infrastructure is the driving force of economic growth. From the allocation of public and private financing, infrastructure is seen as a locomotive for national and regional development. Infrastructure is also important for improving the quality of life and human well-being, among others in increasing the value of consumption, increasing labor productivity and access to employment, as well as a real increase in prosperity. Infrastructure also has an important influence on increasing the value of consumption, increasing labor productivity, and access to employment.

The results of this study are following neoclassical theories on economic growth that consider production factors that are considered highly influential to output growth are the number of labor and capital (capital). Also, the results of this study are the following research conducted by Atmaja and Mahalli (2015) in Sibolga City on the influence of infrastructure on economic growth. The results showed that infrastructure, especially water, has a positive and significant relationship to economic growth in Sibolga City.

\section{Conclusion}


From the analysis and testing of data using the regression data panel (Fixed effect model) can be concluded that capital expenditure and general allocation fund (DAU) in West Sulawesi Province have a positive and significant effect on economic growth. DAU relationship of West Sulawesi Province with economic growth, namely in terms of demand. The amount of DAU funds is largely allocated to civil servant salaries so that it greatly affects consumption through a demand-side mechanism that causes a multiplier effect, which will ultimately affect overall economic activity. The relationship between capital expenditure and economic growth in West Sulawesi province lies in the allocation of capital expenditures to improve the quality of infrastructure.

\section{References}

[1] Sjafrizal, S.:Ekonomi Regional: Teori dan Aplikasi. Padang: Baduose Media, (2008).

[2] Saragih, J. P.:Desertasi Fiskal dan Keuangan Daerah dalam Otonomi. Jakarta: Penarbit Ghalia Indonesia, (2004).

[3] Kuncoro, M.:Ekonomi Pembangunan: Teori, Masalah dan Kebijakan. Jakarta: STIM YKPN, (2004).

[4] Halim, A.:Analisis Keuangan Daerah. Jakarta: Salemba Empat, (2004).

[5] Nopiani, N.Cipta, W.and Yudiaatmaja, F.: Pengaruh Pendapatan Asli Daerah, Dana Alokasi Umum, Dan Belanja Modal Terhadap Pertumbuhan Ekonomi, J. Manaj. Indones., vol. 4, no. 1, (2016).

[6] Verbeek, M.:A Guide to Modern Econometrics. Sussex: John Wiley \& Sons, Ltd, (2000).

[7] Insukindro, M. and Aliman, A.: Ekonometrika Dasar Dan Penyusunan Indikator Ekonomi Unggulan. Makassar, (2001).

[8] Geisser, S.: The Predictive Sample Reuse Method With Applications, J. Am. Stat. Assoc., vol. 70, no. 350, pp. 320-328, (1975), doi: 10.2307/2285815.

[9] Borenstein, M.Hedges, L.and Rothstein, H. R.:Fixed-effect versus random-effects models. Introduction to meta-analysis. (2009).

[10] Widarjono, A.: Penduduk Dan Pertumbuhan Ekonomi Di Indonesia: Analisis Kausalitas, J. Emerg. Mark., vol. 4, no. 2, pp. 147-169, (2016).

[11] Nwakuya, M. and Ijomah, M.: Fixed Effect Versus Random Effects Modeling In A Panel Data Analysis: A Consideration Of Economic And Political Indicators In Six African Countries, Int. J. Stat. Appl., vol. 7, no. 6, pp. 275-279, (2017), doi: 10.5923/j.statistics.20170706.01.

[12] Atmaja, H. K. and Mahalli, K.: Pengaruh Peningkatan Infrastruktur Terhadap Pertumbuhan Ekonomi Di Kota Sibolga, J. Ekon. dan Keuang., vol. 3, no. 4, (2015). 